\title{
Yield analysis of oyster mashroom (Pleurotus ostreatus) on Ficus religiosa leaves in combination with agricultural waste materials
}

\author{
Ali Tahir ${ }^{1}$, Nasir Ahmad Khan ${ }^{1}$, Muhammad Zeeshan Mansha ${ }^{2 *}$, \\ Kamran Ikram ${ }^{3}$, Hafiz Muhammad Usman Aslam ${ }^{4}$, Hafiz Muhammad \\ Aatif ${ }^{2}$, Ch. Muhammad Shahid Hanif ${ }^{5}$ and Muhammad Ashfaq ${ }^{6}$ \\ 1. Department of Plant Pathology, University of Agriculture Faisalabad-Pakistan \\ 2. Department of Plant Pathology, College of Agriculture, Bahauddin Zakariya University, Bahadur Sub Campus, \\ Layyah, Punjab-Pakistan \\ 3. Department of Agricultural Engineering, Khwaja Fareed University of Engineering and Information \\ Technology, Rahim Yar Khan-Pakistan \\ 4. Pest warning and Quality control of Pesticides, Punjab-Pakistan \\ 5. Department of Entomology, College of Agriculture, Bahauddin Zakariya University, Bahadur Sub Campus, \\ Layyah, Punjab-Pakistan \\ 6. Department of Entomology, University of Agriculture Faisalabad-Pakistan \\ *Corresponding author's email: mianzeeshan121@gmail.com
}

Citation

Ali Tahir, Nasir Ahmad Khan, Muhammad Zeeshan Mansha, Kamran Ikram, Hafiz Muhammad Usman Aslam, Hafiz Muhammad Aatif, Ch. Muhammad Shahid Hanif and Muhammad Ashfaq. Yield analysis of oyster mashroom (Pleurotus ostreatus) on Ficus religiosa leaves in combination with agricultural waste materials. Pure and Applied Biology. Vol. 10, Issue 1, pp12-18. http://dx.doi.org/10.19045/bspab.2021.100002

\begin{tabular}{llll}
\hline \hline Received: 05/05/2020 & Revised: 09/08/2020 & Accepted: 13/08/2020 & Online First: 25/08/2020 \\
\hline \hline
\end{tabular}

\section{Abstract}

Oyster mushrooms are one of the most common types of cultivated mushrooms in the world. The current research was conducted to evaluate different agricultural wastes to improve the yield production of oyster mushroom. In the present research, five concentrations $\left(\mathrm{T}_{1}=100 \%\right.$ Ficus leaves, $\mathrm{T}_{2}=75 \%$ Ficus leaves $+25 \%$ Agri. waste, $\mathrm{T}_{3}=50 \%$ Ficus leaves $+50 \%$ Agri . waste, $\mathrm{T}_{4}=25 \%$ Ficus leaves $+75 \%$ Agri. waste and $\mathrm{T}_{5}=0 \%$ Ficus leaves $+100 \%$ Agri. waste) of various agricultural wastes namely wheat straw, corn meal, cotton waste and thatch grass were used along with $F$. religiosa leaves. The experiment was conducted in under completely randomized design (CRD) with three replications. It was observed that the treatment $\mathrm{T}_{3}$ expressed more yield (413.48 g) as compared to the other treatments viz., $\mathrm{T}_{4}=376.65 \mathrm{~g}, \mathrm{~T}_{5}=$ $340.91 \mathrm{~g}, \mathrm{~T}_{2}=292.64 \mathrm{~g}$ and $\mathrm{T}_{1}=250.49 \mathrm{~g}$, respectively, in all the three flushes. It was concluded that the yield production and biological efficacy of treatment 3 containing 50\% Ficus leaves + $50 \%$ Agri. waste were highly useful to enhance the yield of oyster mushroom and can be used in future.

Keywords: Ficus religiosa; Growth chamber; Oyster mushroom; Yield assessment

\section{Introduction}

Almost 200 species of edible mushrooms are present in natural surroundings, but only 22 species are widely cultivated in different areas of the world. Oyster mushroom
(Pleurotus species) is commercially grown on a large scale in many countries. It is an important commodity in the world mushroom market [1]. It belongs to phylum Basidiomycota, class Basidiomycetes and 
family Agaricaceae of the kingdom Fungi. Oyster mushroom is known as wood decomposers and grown on dung piles, water conduits, hilly ranges, in timberland, hardwood, on wood biproducts (paper, sawdust, pulp sludge), all cereal straws, sugarcane bagasse, corn cobs, coffee residues (stalks, coffee grounds, leaves, hulls), cottonseed hulls, soy pulp and banana fronds frequently during and after rain. The fruiting bodies of mushroom are pink, gray to dark brown in color with different sizes ranging from $4-15 \mathrm{~cm}$. The fruiting bodies of wild species appear in autumn; however, it is also observed during winter or in early warm springs. $P$. ostreatus is tolerant to low temperature but have high requirements of light because it is incapable to produce fruiting bodies under low light conditions [2].

Mushrooms are highly consumed due to their delicacy, aroma and texture. On dry weight basis, these contain about $39.91 \%$ carbohydrates, $17.54 \%$ proteins and $2.93 \%$ fats [3]. Some mushroom species are consumed due to excellent source of digestible proteins, fibers, carbohydrates and vitamins. Various edible species of Pleurotus are cultivated all over the world such as $P$. ostreatus, $P$. florida, $P$. salignus, $P$. columbinus, $P$. spodoleucus, $P$. pulmonarius and subspecies are $P$. sapidus, $P$. sajor-caju etc. Among all of these species, $P$. ostreatus is widely consumed and much easier to cultivate on biological waste materials due to its higher nutritional value [4].

$P$. ostreatus can be cultivated on several kinds of substrates/ waste material, having lignin and cellulose components, Due to its shorter growth period, less confronted by pest and disease as compared to the other consumable mushrooms, it can easily be managed [5]. Different agro-industrial wastes along with their different combinations have been used to evaluate the yield or quality production of $P$. florida and proved effective [6].

An experiment was conducted to analyze the nutritional values, minerals and growth of oyster mushroom by applying substrates in pure and mixed form. The pure substrate contained sawdust of Daniella olivery tree and the other substrate was a combination of (Mulainaner+ Daniella olivery tree) mixed with rice bran, rubber neck and calcium carbonate in different percentages, respectively. The growth limitations of mushroom picked from pure substrate was slightly healthier than the mixed substrate but the later one had the better nutritional compositions than the pure substrates [7]. $F$. religiosa is usually known as Bohar, in Subcontinent. It is a gigantic and semideciduous thinning out tree of $2100 \mathrm{~cm}$ range. Its leaves are prevalent or elliptical with spikes like endings. It is one of the prehistoric tree in the God's creatures. It may be monoecious or dioecious [8]. $F$. religiosa is a source of carbohydrates (cellulose, hemicelluloses, pectin) vitamin B6, copper, dietetic fibers, nitrogen, iron and magnesium. In therapeutic field, its leaves are used for Jaundice treatment, the sticky stuff of leaves or fruits may be used as therapy to treat snake bite. Its fruits are consumed by birds, livestock and other animals [9].

Agricultural waste material like sugarcane bagasse, paddy straw, maize cob and saw dust are valuable source for the production of oyster mushroom when they are mixed in various concentration, as they are rich source of cellulose therefor, they have a better capacity for the cultivation of mushroom [10].

Banana leaves having larger amount of cellulose in combination with wheat straw, rice straw and saw dust with different weight ratios are good compost for the production of Pleurotus species with an average daily temperature of $26-30^{\circ} \mathrm{C}$ and relative humidity of $80-100 \%$ [11].

Bioconversion of agriculture waste materials has been proved to be commercially helpful in the production of mushroom by using them as substrate [12]. In Pakistan, India and Bangladesh, the trade of oyster mushroom is increasing due to its pharmaceutical consumption and nutritious 
inference. $F$. religiosa leaves are considerably used for the production of oyster mushroom along with other agricultural waste materials including corn meal straws of wheat, cotton waste and thatch grasses due to its promising source of essential nutrients. Ficus leaves enhance the production of mushroom and consequently prove to be helpful for minimizing the malnutrition [13]. Therefore, the present research was planned to use the $F$. relegiosa leaves as agricultural waste substrate to increase the yield performance of $P$. ostreatus.

\section{Aim of the experiment}

Nearly $75 \%$ population of Pakistan indirectly depends on agriculture and most of the people are predominately attached to the farming community. The present study was designed to assess the suitability of spawn in production and also to cultivate the $P$. ostreatus mushroom on different nutrient rich agricultural waste materials.

\section{Materials and Methods}

The experiment was conducted, during 2017-18, in the mushroom cultivation chamber, Institute of Horticulture sciences, UAF under CRD with three replications. In the current research, $F$. religiosa leaves were used in combination with different agricultural waste materials viz., wheat straw, corn meal, waste of cotton and thatch grass by using five treatments with three replications (Table 1). Gypsum and wheat bran were added to maintain the $\mathrm{pH}$ level of the substrate.

Table 1. Formation of treatments according to their proportion

\begin{tabular}{|c|c|c|}
\hline \multirow[b]{2}{*}{ Treatments } & \multicolumn{2}{|r|}{ Substrate Ratios \% } \\
\hline & Ficus religiosa leaves & $\begin{array}{c}\text { Agricultural waste material (wheat straw+ cotton } \\
\text { waste+ corn meal+ thatch grass) }\end{array}$ \\
\hline T1 & $100 \%$ & $0 \%$ \\
\hline $\mathrm{T} 2$ & $75 \%$ & $25 \%$ \\
\hline T3 & $50 \%$ & $50 \%$ \\
\hline $\mathrm{T} 4$ & $25 \%$ & $75 \%$ \\
\hline T5 & $0 \%$ & $100 \%$ \\
\hline
\end{tabular}

\section{Substrate preparation}

The leaves of $F$. religiosa were used along with other additive substrates namely wheat straw, corn meal, waste of cotton and thatch grass for the cultivation of oyster mushroom. All substrates were collected from the fields of Department of Forestry and Agronomy, UAF. The leaves were chopped into $5-7 \mathrm{~cm}$ pieces, soaked in fresh water for $6-8 \mathrm{hrs}$ and sterilized in hot water for 2-3hrs at Mycology Lab, Department of Plant Pathology, UAF. The substrates after sterilization were spread on polyethylene sheet under sunlight for 10 days to transpire the excessive water.

Substrates such as wheat straw, cotton waste, corn meal and thatch grass were chopped into $5-7 \mathrm{~cm}$ pieces and soaked in fresh water for 6-8hrs and sterilized in hot water for $2-3 \mathrm{hrs}$. After that, the substrate was dried till it contains $60-70 \%$ moisture contents. Spawning was done at $4 \%$ by wet weight of the prepared substrate. Cultivation was done in polyethylene bags of $0.002 \mathrm{~cm}$ thickness [14].

\section{Cultivation of oyster mushroom}

The fermented substrates were packed in heat tolerant polypropylene bags $(24.8 \times 17 \mathrm{~cm})$. The bags contained $500 \mathrm{~g}$ of substrates along with different concentrations of treatments. Afterwards, the bags were air tightened by using a rubber band and autoclaved at $121^{\circ} \mathrm{C}$ with $15-20$ psi pressure for $20 \mathrm{~min}$. Subsequently, $15 \mathrm{~g}$ fresh spawn culture was inoculated in each bag under controlled conditions. The temperature and humidity of the growth chamber were maintained at $20-25^{\circ} \mathrm{C}$ and $80-90 \%$, correspondingly. The fruiting bodies were sprouted after 7-10 days. 
Calculation of biological efficiency

Biological efficiency of each bag of the substrate was calculated by using the formula [15].

Biological Efficiency $(\%)=\frac{\text { Fresh weight of mushroom harvested }}{\text { Substrate }} \times 100$

\section{Statistical analysis}

The statistical analysis was performed through statistical software Statistix v. 8.1. The means of treatments were compared using Fisher's least significant difference (LSD) test at $0.05 \%$ probability level.

\section{Results and Discussion}

All the substrates supported the production of $P$. ostreatus. However, the time required for the initiation and completion of fruiting bodies was significantly reduced by $\mathrm{T}_{3}$ having $50 \%$ of $F$. religiosa leaves $+50 \%$ of agri. waste material compared to $-\mathrm{T}_{4}, \mathrm{~T}_{5}, \mathrm{~T}_{2}$ and $\mathrm{T}_{1}$, respectively.

This experiment was conducted to find out the suitability of locally available substrates for the production of $P$. ostreatus. $F$. religiosa leaves along with different agriculture waste materials (cotton waste, wheat straw, corn meal and thatch grass) were applied and the significant results were obtained. In general, $F$. religiosa leaves along with other agri. waste material (50:50) were found to be superior to the other treatments made during this study.

It was examined that among all the treatments $\mathrm{T}_{3}(50 \%$ Ficus leaves $+50 \%$ agri. waste) took minimum days (26) for the development of $100 \%$ mycelial growth in bags. On the other hand, the longest period was taken by the treatment $\mathrm{T}_{1}(100 \%$ Ficus leaves) took 35 days for the development of $100 \%$ mycelial development. The remaining treatments took various number of days such as $\mathrm{T}_{4}(25 \%$ Ficus leaves $+75 \%$ agri. waste) took 28 days, treatment $\mathrm{T}_{5}(0 \%$ Ficus leaves $+100 \%$ agri. waste) took 30 days and treatment $\mathrm{T}_{2}$ (75\% Ficus leaves + $25 \%$ agri. waste) took 31 days as a substrate. It was observed that the treatment $\mathrm{T}_{3}(50 \%$ Ficus leaves $+50 \%$ agri. waste) showed good results than the other treatments (Table 2). The completion of $100 \%$ of mycelial growth took 26-35 days after spawning and similar results were given by the researchers [16].

There is significant variance among all the treatments used for the production of mushroom, showing valuable results by producing pinheads within days after complete mycelial growth. Bags containing equal quantity of substrates $(F$. religiosa leaves+ Agri. waste material) produced sprouts in early days compared to other treatments which took 54 days. On the other hand, the longest period was taken by the treatment $T_{1}$ (100\% Ficus leaves) 67 days for the formation of pinheads. The results of the other treatments for the formation of pinheads were; $\mathrm{T}_{4}(25 \%$ Ficus leaves $+75 \%$ agri. waste) took 57 days, treatment $\mathrm{T}_{5}(0 \%$ Ficus leaves $+100 \%$ agri. waste) took 60 days and treatment $\mathrm{T}_{2}$ (75\% Ficus leaves + $25 \%$ agri. waste) took 62 days, respectively. It was observed that the treatment $\mathrm{T}_{3}(50 \%$ Ficus leaves $+50 \%$ agri. waste) showed statistically better results than the other treatments $[17,18]$.

After the complete development of pinheads, the fruiting bodies started to emerge from the bags. It was examined that among all the treatments $\mathrm{T}_{3}(50 \%$ Ficus leaves $+50 \%$ agri. waste) started to produce the fruiting bodies within nine days while the treatment $T_{1}(100 \%$ Ficus leaves) took 21 days. The remaining treatments took different no. of days to produce fruiting bodies, $\mathrm{T}_{4}(25 \%$ Ficus leaves $+75 \%$ agri. waste) 12 days, $\mathrm{T}_{5}(0 \%$ Ficus leaves $+100 \%$ agri. waste) 16 days and $\mathrm{T}_{2}(75 \%$ Ficus leaves $+25 \%$ agri. waste) 19 days, respectively. Overall, the treatment $\mathrm{T}_{3}(50 \%$ Ficus leaves $+50 \%$ agri. waste) showed highly significant results than the other treatments. The same outcome was given by [19] while using waste paper in supplementation with rice bran. 
Table 2. Assessment means for the growth development of oyster mushroom (Days)

\begin{tabular}{|c|c|c|c|}
\hline Treatments & $\mathbf{1 0 0} \%$ Mycelial growth & Pin head formation & Dev. of fruiting bodies \\
\hline $\mathrm{T}_{1}$ & $35.40 \pm 0.011 \mathrm{~A}$ & $67.40 \pm 1.02 \mathrm{~A}$ & $21.20 \pm 0.58 \mathrm{~A}$ \\
\hline $\mathrm{T}_{2}$ & $31.60 \pm 0.007 \mathrm{~B}$ & $62.00 \pm 1.09 \mathrm{~B}$ & $19.20 \pm 0.50 \mathrm{~B}$ \\
\hline $\mathrm{T}_{3}$ & $26.81 \pm 0.010 \mathrm{E}$ & $54.40 \pm 1.02 \mathrm{D}$ & $9.00 \pm 0.70 \mathrm{E}$ \\
\hline $\mathrm{T}_{4}$ & $28.82 \pm 0.014 \mathrm{D}$ & $57.60 \pm 1.07 \mathrm{C}$ & $12.60 \pm 0.50 \mathrm{D}$ \\
\hline $\mathrm{T}_{5}$ & $30.21 \pm 0.013 \mathrm{C}$ & $60.80 \pm 1.11 \mathrm{~B}$ & $16.20 \pm 0.58 \mathrm{C}$ \\
\hline
\end{tabular}

LSD of treatment means were compared at significance at $p \leq 0.05, \mathrm{~T}_{1}=$ Ficus leaves $100 \%, \mathrm{~T}_{2}=$ Ficus leaves $75 \%$ + agri. waste $25 \%, \mathrm{~T}_{3}=$ Ficus leaves $50 \%+$ agri. waste $50 \%, \mathrm{~T}_{4}=$ Ficus leaves $25 \%+$ agri. waste $75 \%, \mathrm{~T}_{5}=$ Ficus leaves $0 \%+$ agri. waste $100 \%$

\section{Yield analysis}

The average weight of mushroom yield in first flush was higher in $\mathrm{T}_{3}(150.75 \mathrm{~g})$ while lowest in treatment $\mathrm{T}_{1} 94.31 \mathrm{~g}$, while the remaining treatments namely $\mathrm{T}_{4}, \mathrm{~T}_{5}$ and $\mathrm{T}_{2}$ had $137.33 \mathrm{~g}, 123.84 \mathrm{~g}$ and $108.41 \mathrm{~g}$ yield of mushroom, respectively, in the first flush (Table 3). The results of the present experimental trial regarding yield in first flush are in close conformity with the investigation of [20] whose resutls showed $89-146 \mathrm{~g}$ yield of mushroom from the first flush.

Similarly, $\mathrm{T}_{3}$ produced average yield of $136 \mathrm{~g}$ in the second flush of mushroom as compared to other treatments which include viz., $\mathrm{T}_{1}$ (81.21g), $\mathrm{T}_{4}(122.24 \mathrm{~g}), \mathrm{T}_{5}(118.48 \mathrm{~g})$ and $\mathrm{T}_{2}(98.314 \mathrm{~g})$, respectively (Table 3 ).

The third and last flush of mushroom expressed less amount of yield with low nutrient values. The high weight of yield was shown by $\mathrm{T}_{3}$ treatment $(126.15 \mathrm{~g})$ whereas $\mathrm{T}_{1}$ treatment expressed least amount of mushroom that was $74.96 \mathrm{~g}$. Likewise, all other treatments such as $\mathrm{T}_{4}, \mathrm{~T}_{5}$ and $\mathrm{T}_{2}$ exhibited $117.08 \mathrm{~g}, 98.90 \mathrm{~g}$ and $85.90 \mathrm{~g}$ of mushroom yield, respectively (Table 3). The total mean yield observed from all the treatments of this experiment varied from 413-250g and are considerably in line with the findings of [17] who used the wheat straw and [21] they used 50\% sisal leaves $+50 \%$ sisal boles and observed $450 \mathrm{~g}$ of maximum mushroom yield.

It was observed that the biological efficiency of $P$. ostreatus mushroom varied to utilize different substrates for producing yield. Highest biological efficiency $82.70 \%$ recorded in case of $\mathrm{T}_{3}$ (50\% Ficus leaves+ $50 \%$ Agri. waste) followed by $\mathrm{T}_{4}(25 \%$ Ficus Leaves+ $75 \%$ Agri. waste) $75.32 \%$, $\mathrm{T}_{5}$ (0\% Ficus Leaves+ $100 \%$ Agri. waste) $68.18 \%, \mathrm{~T}_{2}(75 \%$ Ficus Leaves+ 25\% Agri. Waste) $58.52 \%$ and Treatment $\mathrm{T}_{1}(100 \%$ Ficus Leaves) $50.09 \%$ respectively (Table $3)$. The outcomes of this experiment are in line with $[22,23]$ who reported $85 \%$ and $77 \%$ of biological efficiency of Pleurotus spp. in paddy straw and wheat straw.

Table 3. The yield and biological efficiency of oyster mushroom on different treatments

\begin{tabular}{|c|c|c|c|c|c|}
\hline Treatments & $\mathbf{1}^{\text {st }}$ flush & $\mathbf{2}^{\text {nd }}$ flush & $\mathbf{3}^{\text {rd }}$ flush & Total yield & B.E (\%) \\
\hline $\mathrm{T}_{1}$ & $94.31 \pm 1.22 \mathrm{E}$ & $81.21 \pm 0.96 \mathrm{E}$ & $74.96 \pm 1.19 \mathrm{E}$ & $250.49 \pm 2.67 \mathrm{E}$ & $50.09 \pm 0.53 \mathrm{E}$ \\
\hline $\mathrm{T}_{2}$ & $108.41 \pm 1.22 \mathrm{D}$ & $98.31 \pm 1.29 \mathrm{D}$ & $85.90 \pm 0.93 \mathrm{D}$ & $292.64 \pm 2.39 \mathrm{D}$ & $58.52 \pm 0.47 \mathrm{D}$ \\
\hline $\mathrm{T}_{3}$ & $150.75 \pm 0.97 \mathrm{~A}$ & $136.58 \pm 0.92 \mathrm{~A}$ & $126.15 \pm 0.87 \mathrm{~A}$ & $413.48 \pm 1.42 \mathrm{~A}$ & $82.70 \pm 0.28 \mathrm{~A}$ \\
\hline $\mathrm{T}_{4}$ & $137.33 \pm 1.04 \mathrm{~B}$ & $122.24 \pm 0.99 \mathrm{~B}$ & $117.08 \pm 0.99 \mathrm{~B}$ & $376.65 \pm 1.16 \mathrm{~B}$ & $75.32 \pm 0.23 \mathrm{~B}$ \\
\hline $\mathrm{T}_{5}$ & $123.84 \pm 1.02 \mathrm{C}$ & $118.48 \pm 0.92 \mathrm{C}$ & $98.90 \pm 1.10 \mathrm{C}$ & $340.91 \pm 0.95 \mathrm{C}$ & $68.18 \pm 0.19 \mathrm{C}$ \\
\hline
\end{tabular}

LSD of treatment means were compared at significance at $p \leq 0.05, \mathrm{~T}_{1}=$ Ficus leaves $100 \%, \mathrm{~T}_{2}=$ Ficus leaves $75 \%$ + agri. waste $25 \%, \mathrm{~T}_{3}=$ Ficus leaves $50 \%+$ agri. waste $50 \%, \mathrm{~T}_{4}=$ Ficus leaves $25 \%+$ agri. waste $75 \%, \mathrm{~T}_{5}=$ Ficus leaves $0 \%+$ agri. waste $100 \%$, B.E $=$ Biological efficiency

\section{Conclusion}

In view of the above study, it can be concluded that the yield contributed characteristics and biological efficiency of
$\mathrm{T}_{3}$ ( $F$. religiosa leaves along with other agri. waste material (50:50) was maximum $413.48 \mathrm{~g}$ in minimum days. The combination of main substrate along with 
other agri. waste materials for the production of oyster mushroom showed an opportunity for commercial cultivation when they were used in combined form.

\section{Authors' contributions}

Conceived and designed the experiments: NA Khan, Performed the experiments: A Tahir, Analyzed the data: K Ikram \& M Ashfaq, Contributed materials/ analysis/ tools: HM Aatif \& Ch. MS Hanif, Wrote the paper: MZ Mansha \& HMU Aslam.

\section{Acknowledgement}

The authors greatly acknowledge the Department of Plant Pathology and Institute of Horticultural Sciences, University of Agriculture Faisalabad for the kind assistance in providing the laboratory facilities and all the required consumable equipment during the entire period of this research work.

\section{References}

1. Adebayo EA, Oloke JK, Ayandele AA \& Adegunlola CO (2012). Phytochemical, antioxidant and antimicrobial assay of mushroom metabolite from Pleurotus pulmonarius -LAU 09 (JF736658). J Microbiol Biotech Res 2(2): 366-374.

2. Wojewoda W (2003). Checklist of Polish Larger Basidi-omycetes, Critical list of large-core basic fungi of Poland, series: Biodiversity of Poland. Vol 7. W. Szafer Institute of Botany: Polish Academy of Sciences Krakow, Poland. pp. 812.

3. Demirba A (2001). Heavy metal bioaccumulation by mushrooms from artificially fortified soils. Food Chem 74: 293-301.

4. Heleno SA, Barros L, Sousa MJ, Martins A \& Ferreira ICFR (2009). Study and characterization of selected nutrients in wild mushrooms from Portugal by gas chromatography and high-performance liquid chromatography. Microchem $J$ 93: 195-199.

5. Dehariya P \& Deepak V (2015). Evaluation of different spawns and substrates on growth and yield of
Pleurotussajor-caju. Int J Recent Sci Res 6: 2908-2911.

6. Sardar H, Muhammad AA, Amir N, Shaghef E, Muhammad AA, Nasir AK, Faheem N \& Muhammad R (2016). Impact of various agro-industrial wastes on yield and quality of Pleurotus Sajor caju. Pak J Phyto 28(1): 87-92.

7. Ogundele GF, Abdulazeez RO \& Bamidele OP (2014). Effect of pure and mixed substrates on oyster mushroom (Pleurotus ostratus) cultivation. J Exp Biol Agri Sci 2:2S.

8. Berg CC, Corner EJH \& Nooteboom HP (2005). Flora Malesiana. Series I, Seed Plants. Vol 17(2). National Herbarium Nederland; Leiden (Nederland). 730p.

9. Orwa C, Mutua A, Kindt R, Jamnadass R \& Anthony S (2009). Agroforestry Tree Database: A tree reference and selection guide. Ed 4.

10. Situla HP, Dhakal R, Gateesh DC \& Kalauni D (2018). Effect of various substrates on growth and yield performance of oyster mushroom (Pleurotus ostreatus) in Chitwan, Nepal. Int J App Sci Biotech 6(3): 215219.

11. Neupane S, Viwek T, Bikram B, Prakash P, Bhanu BG \& Laxman A (2018). Performance of different substrates on the production of oyster mushroom (Pleurotus florida) at Gokuleshwor, Darchula. Int J Sci Res Pub 8(6): 231-240.

12. Adebayo EA, Oloke JK, Azeez MA, Omomowo IO \& Bora, TC (2014a). Assessment of the genetic diversity among ten genotypes of Pleurotus (oyster mushroom) using nutrient and mineral compositions. Sci Hortic 166: 59-64.

13. Eswarn A \& Ramabadran (2000). Studies on some Physiological, Cultural and Postharvest Aspects of Oyster Mushroom, Pleurotus eous (Berk.) sacc. Trop Agri Res 12: 360374. 
14. Pani BK \& Das SR (1998). Seasonal productivity of white summer mushroom (Calocybe indica P. \& C.) in Orissa. Sci Cult 64: 177-178.

15. Royse, DJ, Rhodes TW, Ohga S \& Sanchez JE (2004). Yield, mushroom size and time to production of Pleurotus cornucopiae (oyster mushroom) grown on switch grass substrate spawned and supplemented at various rates. Biol Resour Tech 19: 8591.

16. Fan L, Pandey A, Mohan R \& Soccol CR (2000). Use of various coffee industry residue for the cultivation of Pleurotus Ostreatus in solid state fermentation. Acta Biotech 20(1):4152.

17. Pathmashini L, Arulnandhy V \& Wijeratnam RS (2008). Cultivation of oyster mushroom (Pleurotus Ostreatus) on sawdust. Cey J Sci (Bio Sci) 37(2): 177- 182.

18. Eksittikul T \& Sanya K (2010). Effect of chitosan biopolymer on oyster mushroom Pleurotus Ostreatus (Fr.) Kummer cultivation. J Biotech (150): 327-327.
19. Pokhrel CP (2016). Cultivation of oyster mushroom: a sustainable approach of rural development in Nepal. J Inst Sci Tech 21(1): 56-60.

20. Mane VP, Shyam SP, Abrar AS \& Mirza MVB (2007). Bioconversion of low quality lignocellulosic agricultural waste into edible protein by Pleurotus sajor-caju (Fr.) Singer. J Zhejiang Univ Sci B 8(10): 745-751.

21. Raymond CM, Gerald GS, Karina B, Joanna RB, Jordan L, Harry N, Nancy JT, Bryan N, Jordan T \& Kai MAC (2013). Ecosystem services and beyond: Using multiple metaphors to understand human-environment relationships. Bio Sci 63(7): 536-546.

22. Dhandana SS, Sethi GS \& R Behl (2004). Indices of Drought Tolerance in Wheat Genotypes at Early Stages of Plant Growth. J Agro Crop Sci 190(1): 6-12.

23. Khan MW, Muhammad AA, Nasir AK, Muhammad AK, Abdul R \& Nzir J (2013). Effect of different levels of lime and ph on mycelial growth and production efficiency of oyster mushroom (pleurotus spp.). Pak J Bot 45(1): 297-302. 